\title{
OBITUARIES
}

Obituaries should be submitted by email to Laura Pacey at I.pacey@nature.com.

All submitted obituaries should be 450 words maximum in length (apart from obituaries for past presidents of the BDA where the length should be 800 words).

Content of the obituary is down to the individual author, and the approval of the family should

be given for the obituary prior to submission to the $B D J$.

\section{WILLIE MADEN}

\section{9-2013}

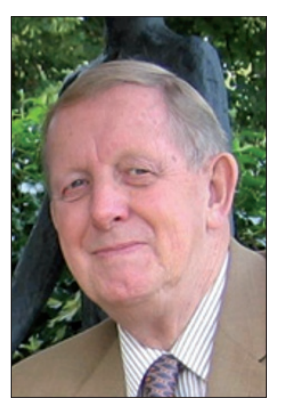

Bill Maden died on 14 October 2013 at the age of 84 .

He was born on 7 June 1929 and lived his early life in Bacup, Lancashire, attending the Bacup and Rawtenstall Grammar School. He attended

Manchester University, qualifying as a dentist in 1951. He then served in the army as a captain in the Royal Army Dental Corps, mainly in Hong Kong.

After army service, he settled on the Isle of Wight as the school dentist in Newport, working at Nine Acres School. He was promoted to Chief Dental Officer and in 1974 he was appointed Area Dental Officer. When the area was removed in 1982, he went into general practice with Ian Poplett and Roy Burrows in Ventnor, also working at Whitecroft Hospital and HM Prison, Albany. He was also the Postgraduate Dental Tutor at St Mary's Hospital.

He was a keen member of the British Dental Association and served as chairman and secretary of the local section. He became Chairman of the Wessex Community Dental Service Group and President of the Wessex Branch and was appointed as a Life Member.

He practised hypnosis and was a Fellow of the British Society of Medical and Dental Hypnosis and the Royal Society of Medicine.

He was a former Master of Ryde Masonic Lodge (698) and a Past President and Paul Harris Fellow of the Rotary Club of Newport. He was a former member of the Board of Visitors at HM Prison, Albany and a former chairman of the Friends of the Isle of Wight Ambulance Service.

He leaves his wife, Jean, four children and six grandchildren.

\section{BERNARD CAPLAN}

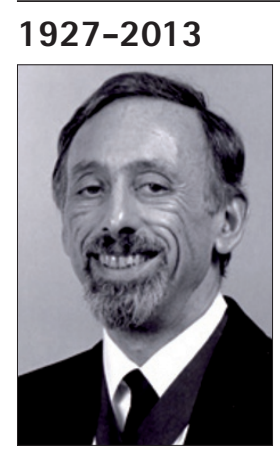

Bernard Caplan, a proud native of Glasgow, passed away on 30 September 2013 aged 86. One of the last LDS graduates of Glasgow's Anderson College of Medicine in 1950 he served two years

as an RAF flight lieutenant dental officer before returning to Glasgow to set up in practice.

In mid-career, Bernard joined Glasgow LDC serving as dental secretary for 21 years. This re-invigorated his dental interest and led him to being elected to represent his colleagues on almost every Scottish and UK BDA committee, holding high office in each. His LDC passion led to Bernard chairing the 1982 annual conference.

Amongst dentists, Bernard had an unusually clear understanding of both superannuation and the remuneration formulae to develop the 'fee scale'. Hence he would spend his leisure time answering calls from GDPs from all over the UK explaining these concepts to baffled colleagues.

Bernard also led the concept of GDPs working in health centres, developing his famous 'Woodside Terms' and then being first to work thus in Gorbals Health Centre. He also found an affinity with students, heading and chairing both the BDA students and the Scottish VT committees.

His work for the profession was honoured by his award of an honorary Diploma in General Dental Practice (DGDP) by the Faculty and his Fellowship of the BDA in 1995. He also represented the profession at several royal garden parties.

Bernard had three favoured neckties: Glasgow Dental Alumnus, BDA and Dental Rates Study Group, wearing each of them proudly and enthusiastically.

In retirement, Bernard maintained his dental interest by acting as a trustee and secretary to the British Dental Guild until only two years ago, allowing him to travel and stay at his treasured Royal Society of Medicine.

Bernard's first and greatest love was for his family and especially his beloved wife of 62 years, Yetta. They met as young students in 1945 and were inseparable for 68 years, travelling widely and sharing life's opportunities.

He is survived by Yetta, his brother Philip, sons Ricky, Mervyn and Alan and five granddaughters. He will be fondly remembered with affection and respect by his dental colleagues and patients.

Alan Caplan and Kieran Fallon 